\title{
FUNDAMENTOS HISTÓRICO-CONSTITUCIONAIS DO SISTEMA ELEITORAL DOS ESTADOS UNIDOS DA AMÉRICA
}

Antônio Celso Alves Pereira ${ }^{1}$

\section{Resumo}

O objetivo principal deste artigo é discutir o processo de criação, pelos "Pais Fundadores" dos Estados Unidos da América, do Sistema Eleitoral do país e sua evolução histórico-constitucional, a partir da XII Emenda (1804) à Constituição de 1787. Busca também analisar do papel dos Estados membros da União na construção do Sistema, o desenvolvimento e a atualidade da estrutura partidária e os fundamentos ideológicos do Colégio Eleitoral, que escolhe o presidente e o vice-presidente, e que estão expressos nos Artigos Federalistas.

Palavras-chave: Sistema Eleitoral dos Estados Unidos. Constituição Norte-Americana. Artigos Federalistas. Colégio Eleitoral.

\section{INTRODUÇÃO}

A Revolução das Treze Colônias norte-americanas contra a Metrópole britânica expressou um dos grandes momentos da história política, jurídica e econômica do Ocidente, no período de transição da Idade Moderna para a Idade Contemporânea. Pelos seus desdobramentos, e por sua inegável e perene influência sobre outros povos, sobretudo as Repúblicas que, posteriormente, surgiriam no Continente Americano, deu origem à formação e à consolidação do mais poderoso Estado já conhecido, desde o fim da hegemonia imperial romana no século V da Era Cristã: os Estados Unidos da América.2 Proclamada a Independência no Segundo Congresso Continental, reunido na Filadélfia, em 4 de julho de 1776, e, cinco anos depois, com a rendição das forças britânicas, em Yorktown, na Virgínia, consolidava-se o movimento separatista iniciado pela revolta contra a excessiva tributação imposta pela Coroa à sua Colônia americana, medida que tinha como objetivo recuperar a economia inglesa, naquela altura, destroçada pelos altos cultos da Guerra dos Sete Anos, ou seja, uma série de conflitos internacionais ocorridos entre 1756 e 1763, consequentes da rivalidade colonial e econômica anglo-

\footnotetext{
${ }^{1}$ Professor do Programa de Pós-Graduação em Direito da Universidade Veiga de Almeida - UVA. Diretor Geral do Centro de Ensino Superior de Valença, RJ. Presidente da Sociedade Brasileira de Direito Internacional. E-mail: acelsopereira@globo.com ${ }^{2}$ Sobre a natureza, a atualidade e as perspectivas futuras do poder hegemônico dos Estados Unidos da América, consultar NYE JR., 2002.
} 
francesa e da luta entre a Áustria e a Prússia pela supremacia na Alemanha. ${ }^{3}$

O objetivo principal deste texto é discutir o processo de criação, pelos "Pais Fundadores" dos Estados Unidos da América, do Sistema Eleitoral do país e sua evolução histórico-constitucional, a partir da XII Emenda (1804) à Constituição de 1787. Busca também analisar do papel dos Estados membros da União na construção do Sistema, o desenvolvimento e a atualidade da estrutura partidária e os fundamentos ideológicos do Colégio Eleitoral, que escolhe o presidente e o vice-presidente, e que estão expressos nos Artigos Federalistas.

\section{A REVOLTA AMERICANA}

A revolta americana iniciara-se em decorrência da imposição de dois impostos, o Sugar Act e o Stamp Act que, embora revogados, em 1766, foram substituídos, em 1767, conforme os chamados Atos Townshend, ${ }^{4}$ por novos tributos sobre o chá, o papel, os vidros e as tintas. Em 1773 ocorria, em Boston, a famosa revolta do chá. Em 05 de setembro de 1774, na Filadélfia, reuniram-se os delegados das Treze Colônias, no Primeiro Congresso Continental, ocasião em que redigiram uma declaração de direitos e exigiram o retorno à situação anterior e a reformulação do Pacto Colonial. O Parlamento britânico repeliu as reivindicações e promulgou as chamadas "Leis de Coerção", altamente repressivas, denominadas “Leis Intoleráveis" pelos colonos revoltados.

Em 1775 começava a guerra de independência que escalou até a vitória final, graças ao apoio financeiro e militar francês, ${ }^{5}$ bem como à integração de tropas espanholas e neerlandesas nos contingentes do Exército

\footnotetext{
${ }^{3}$ Em consequência da amplitude dos conflitos, que ocorreram não somente no continente europeu, mas também nos territórios coloniais das duas principais potências envolvidas, França e Grã-Bretanha, portanto na África, Ásia, Caribe e América do Norte, historiadores incluem a Guerra dos Sete Anos na lista dos conflitos mundiais. Na Europa formaram-se dois blocos militares: um, sob a liderança da França, reunindo a Áustria e a Rússia imperiais, os reinos da Espanha, Suécia, Saxônia, Sardenha, das Duas Sicílias, e o ducado de Wurttemberg; outro, liderado pela Grã-Bretanha, reunia os reinos de Portugal, Prússia, Hanover, o ducado de Brunsvique, o Estado de Hesse-Kassel e até os índios Iroqueses da América do Norte. Em 10 de fevereiro de 1763, pelo Tratado de Paris, as partes beligerantes celebram a paz. A Grã-Bretanha, embora depauperada economicamente pelos altos custos da guerra, foi, militar e politicamente, a grande vencedora do conflito. Contudo, pode-se incluir em seus desdobramentos, a perda de suas (ricas) Treze Colônias norte-americanas.

${ }^{4}$ Os citados tributos foram propostos e aprovados no Parlamento Britânico, por Charles Townshend, em 29 de junho de 1767. Além dos novos impostos, o Parlamento instituiu Tribunais Alfandegários nas Colônias.

${ }^{5}$ No cerco de Yorktown mais da metade das tropas regulares eram francesas, comandadas pelo Marquês de Lafayette e pelo Conde de Rochambeau. A vitória norte-americana nessa batalha só foi possível em razão do suporte da esquadra francesa, sob o comando do almirante de Grasse. O apoio da França à Guerra de Independência dos Estados Unidos, negociado em Paris por Benjamim Franklin, para o governo de Luís XVI, constituía-se em mais um episódio da longa disputa pela supremacia política e comercial global, entre a França e a Grã-Bretanha, que somente se encerraria com a derrota de Napoleão em Waterloo. Tal medida custou 1 bilhão de libras e arruinou as finanças da monarquia francesa. As dificuldades econômicas advindas deste fato incluem-se no rol de fatores que culminaram na Revolução Francesa. Ao tomar conhecimento do apelo dos revolucionários norte-americanos, o rei Luís XVI externou sua posição contrária afirmando o seguinte: "É minha profissão ser partidário da realeza". Contudo, acabou cedendo por pressões oriundas de elementos de seu próprio governo, como o ministro dos Assuntos Exteriores, o Conde de Vergennes, e por lideranças da opinião pública, como - Caron de Beaumarchais, autor de peças teatrais, (O Barbeiro de Sevilha, As Bodas de Fígaro), que arrecadava, com grande apoio popular, fundos para comprar armas para o Exército Revolucionário norte-americano. (JOHNSON, 2001, p. 165-167). Sobre a presença de tropas espanholas e neerlandesas na Revolução Americana a explicação está no fato de que a Grã-Bretanha tomara à Espanha o promontório de Gibraltar, em 1804, confirmando sua posse pelo Tratado de Utrecht, em 1713 e, além disso, naquela época, ocupava militarmente a ilha espanhola de Minorca. Por sua vez, os Países Baixos vol.09, nº. 04, Rio de Janeiro, 2016. pp. 2227-2247 2228
} 
Continental comandado pelo General George Washington. O Tratado de Paris, celebrado em 3 de setembro de 1783, pôs fim à Guerra Revolucionária e redundou no reconhecimento, pela Inglaterra, dos Estados Unidos como Estado independente. ${ }^{6}$

Desde os primórdios de sua formação nacional, a República Americana, por meio de suas lideranças mais expressivas, sempre proclamou a singularidade de sua sociedade nacional pura e virtuosa, única e perfeita, a imagem de uma América "que tem suas raízes no mito amplamente propagado da pureza do Novo Mundo e da corrupção da Europa, noção que encontra suas primitivas articulações, na teocracia setecentista da colônia da baía de Massachusetts" (PARENTI, 1970, p. 47).

Os peregrinos que partiram da Inglaterra no navio Mayflowere em outros navios, em 1620, em direção à América, em busca de liberdade religiosa, estavam convencidos de que lá, em terras virgens, construiriam uma nova sociedade, protegida pelas graças do Criador e livre dos vícios, da corrupção monárquica e da opressão do Velho Mundo. Assim, seguros de sua condição de "novo povo eleito", fundaram a comunidade puritana da qual se originaria os Estados Unidos da América. "O puritanismo não era apenas uma doutrina religiosa: confundia-se ainda, em vários aspectos, com as teorias democráticas e republicanas mais absolutas" (TOCQUEVILLE, 1987 p. 33). Foi a convicção salvacionista de que "agiam pela humanidade inteira" (KISSINGER, 2001, p. 31), que levou os norte-americanos ao mito do destino manifesto, como se pode concluir das palavras de dois "Pais Fundadores", tomados, diga-se de passagem, por arrogante messianismo:

"A mão da própria divindade" conforma a história americana, segundo o jovem Hamilton. [...] "É preciso que muitas centenas de anos passem", disse John Adams, "antes que sejamos corrompidos. Nossa república federativa, pura, virtuosa e orientada pelo espírito público, existirá eternamente, governará o globo e introduzirá a perfeição do homem". (PARENTI, 1970, p.47-48).

Uma vez independentes, as Treze Colônias partiram para a construção de instituições públicas marcadas, em termos político-jurídicos, por um espírito novo, em tudo diferente da tradição monárquica e constitucional europeia. ${ }^{8}$ Os revolucionários norte-americanos tinham consciência, segundo o "Pai Fundador" John Jay, de que "eram o primeiro povo a receber do céu a oportunidade de deliberar e escolher sob que formas de governo deveriam viver" (WOOD, 2013, p. 90). Em razão disso, buscaram construir um Estado laico, ordenado

mantinham com os britânicos um contencioso originário de disputas comerciais, de frequentes embates navais no Mar do Norte e no Báltico, e, principalmente, da tentativa dos ingleses, em 1781, de ocupar o Cabo da Boa Esperança, então controlado pelos neerlandeses (RAPHAEL, 2006, p. 237-241).

${ }^{6} \mathrm{O}$ Tratado de Paris, negociado na França por Benjamim Franklin com o ministro do Exterior de Luis XVI, Charles Gravier, conde de Vergennes e com o representante britânico Thomas Greville, foi ratificado pelos Estados Unidos em 14 de janeiro de 1784.

7 "Os Estados Unidos, desde os primórdios de sua formação nacional, impulsionados pela mística do "destino manifesto", tentaram construir um mundo seguro para a a sua expansão imperial. "A world safe for democracy", em todos os tempos, foi apenas cortina de fumaça para encobrir seus verdadeiros interesses nacionais. Não fora assim, como explicar o decidido apoio que os norteamericanos emprestaram aos regimes de força e às ditaduras em várias partes do mundo" PEREIRA, 1984, p. 30).

8 "Os Estados Unidos da América começaram como um país não muito grande ou importante, mas precocemente consciente de seu grande destino, por estar imbuído por um senso do novo, da sua diferença de tudo o que se experimentara antes" (KIERNAN, V.G. 2009, p. 24). 
pela sociedade civil organizada, e apoiado em um corpo normativo que assegurasse ao cidadão o usufruto das liberdades e garantias individuais, princípios que já estavam consagrados na Declaração de Direitos da Virgínia (12 de junho de 1776), e que, em seguida, constaram da Declaração de Independência (4 de julho de 1776), e foram expressos na Carta de Direitos e Garantias (Bill of Rights), em 1791, ou seja, as dez primeiras emendas à Constituição dos Estados Unidos, ratificada pelos Estados, em junho de 1788. A partir de um novo e, para a época, revolucionário direito público, os "Pais Fundadores" 9 construíram a nova nação elegendo a República como estrutura de Estado e forma de governo, em contraposição ao Estado e ao governo monárquicos.

Os mais destacados "Pais Fundadores" dos Estados Unidos eram homens cultos, versados em Filosofia Política, em História e em Direito, externavam em seus escritos as influências do Republicanismo Clássico, do Humanismo Cívico Renascentista e do Iluminismo e, principalmente, eram leitores de John Locke e Montesquieu, cujas ideias os levaram a construir uma nova modalidade de estruturação dos poderes do Estado, dividindo-os em Executivo, Legislativo e Judiciário, conscientes de que os poderes de fazer a lei, governar, e julgar, estabelecendo o equilíbrio e a harmonia entre os mesmos, para haver liberdade, defesa e proteção da propriedade, jamais deveriam emanar e se concentrar em uma única instituição ou pessoa. A sede do poder estava no povo e a fonte da lei deveria estar em uma Constituição.

Isaac Kramnick, professor de Ciência Política da Universidade de Harvard, na apresentação da edição brasileira dos Artigos Federalistas, informa que James Madison se referia a Montesquieu como 'o oráculo que é sempre consultado nesse assunto' (1993, p. 43). Os “Pais Fundadores” eram homens dotados de sólido realismo e senso prático e, quase todos, tinham servido no Exército Continental. "Em suas reflexões, eles se limitaram a entender o governo segundo a imagem da razão individual e a interpretar o governo sobre os governados de acordo com o velho modelo do domínio da razão sobre a paixão" (ARENDT, 2011, p.135). É interessante observar a preocupação dos fundadores com a educação do povo. Elaboraram planos e os transformaram em ação, criando sistemas públicos de educação que se desenvolveriam de forma ampla no correr do século XIX. Quando se deu a Independência, os Estados Unidos já contavam com nove grandes Universidades. Nos vinte e cinco anos seguintes foram criadas outras dezesseis instituições de ensino superior, compreendendo universidades e faculdades isoladas. ${ }^{10}$

O grande mérito do novo espírito igualitário na América do Norte foi a tomada de consciência de que a educação devia estar, privilegiadamente, entre as prioridades nacionais. [...] Stanhope Smith, reitor de Princeton (fundada em 1746), acreditava que uma combinação de "leis republicanas" e educação causaria uma melhora geral na moral da

\footnotetext{
${ }^{9}$ George Washington, Benjamim Franklin, Alexander Hamilton, Thomas Jefferson, James Madison, John Jay, Thomas Paine, James Wilson, John Adams, John Marshall, Samuel Adams, James Wilson, Gouverneur Morris, Robert Morris, Thomas Mifflin, George Clymer, entre outros.

${ }^{10}$ A elite intelectual que participou na Revolução Americana foi, em grande parte, formada nas Universidades da então Colônia. Antes da Independência, os norte-americanos já contavam comas seguintes Universidades: Harvard, fundada em 1636, Yale, em
} 1701, Pensilvânia, em 1740, Princeton, em 1746, Columbia, em 1754, Brown, em 1764 e Dartmouth College, em 1769. 
população e criaria uma "sociedade uniformemente virtuosa”. [...] Era a educação, sustentava John Adams ( $2^{\circ}$ presidente dos Estados Unidos) que fazia o cavalheiro, e não sua origem ou seus privilégios. [...] Foi a educação o elemento que faria da estrutura republicana e do conteúdo democrático da nova união de Estados instrumentos de progresso pacífico. (JOHNSON, 2001.p. 177)

Logo que se iniciou a luta pela Independência, os líderes do movimento começaram a discutir e a estruturar os necessários arranjos institucionais e o futuro governo e, para tanto, no Congresso Continental, reunido em maio de 1776, exortaram as Treze Colônias, transformadas em Estados, a constituírem "sob a autoridade do povo" seus governos regionais, ao mesmo tempo em que deviam elaborar as constituições estaduais, conformadas à nova realidade política da nação.

\section{AS CONSTITUIÇÕES ESTADUAIS E O CHAMADO "DESPOTISMO DEMOCRÁTICO”. OS ARTIGOS DE CONFEDERAÇÃO}

Entre 1776 e 1777, os Estados elaboraram e aprovaram suas Constituições escritas e fortemente influenciadas pelo pensamento liberal expresso "não só nos tratados políticos de filósofos notáveis como John Locke, mas também os escritos de panfletários populares do século XVIII, como John Trenchard e Thomas Gordon” (WOOD, 2003, p. 85). É interessante salientar que, durante o processo constituinte nos Estados, a grande preocupação dos norte-americanos era impedir que nas Repúblicas em que se transformavam as antigas Colônias, o poder dos administradores e governadores ameaçasse as liberdades fundamentais do cidadão. Nesse período, o esforço maior era no sentido de formar os governos estaduais para facilitar a união de todos no contexto da luta para manter a Independência. O objetivo das Constituições era impedir que, na organização dos governos estaduais, os governadores eleitos para administrar os novos Estados pudessem concentrar o poder e, desta forma, violar os direitos do cidadão, ultrapassar os limites da liberdade. Os constituintes temiam, pela experiência colonial, a força e a tendência dos executivos de agir de forma tirânica. Em razão disso, as Constituições estaduais limitaram o poder dos governadores, passaram a fiscalizá-los por meio de conselhos controladores eleitos pelos Legislativos estaduais. As Assembleias assumiram o poder de nomear para cargos executivos e judiciários, chamaram a si o direito de conceder indultos, estabelecer relações diretas com países estrangeiros, com eles firmar alianças, estabelecer e manter relações comerciais. Ainda nessa direção, atribuíram-se a competência para declarar guerra e firmar a paz. Esses poderes foram conferidos aos Estados pela Declaração de Independência, documento escrito por Thomas Jefferson, que deixava claro que as então Colônias, livres do domínio britânico, podiam "levar a cabo quaisquer decisões ou ações, tal como compete aos Estados Independentes”. Na criação dos seus sistemas eleitorais, os Estados estabeleceram distritos eleitorais iguais, adotaram eleições anuais, passaram a exigir dos eleitores e dos eleitos residência obrigatória nos distritos. 
Na maioria dos Estados o direito de voto era atribuído a quem fosse proprietário. Os Estados de Carolina do Norte e Nova Hampshire permitiam o voto a quem pagasse impostos. Entretanto, em todos os Estados só votavam homens brancos que possuíssem os pertinentes requisitos legais. As mulheres eram consideradas cidadãs, porém, até a promulgação da 19a Emenda à Constituição Federal, em 1920, não podiam votar. Os negros, mesmo livres, somente adquiriram direitos de cidadania, incluído o de voto, em 1870, pela $15^{a}$ Emenda. As normas sobre cidadania eram específicas em cada Estado, porém, era levado em conta o disposto no Primeiro Congresso Continental, ou seja: "Todas as pessoas que residam em qualquer das Colônias Unidas, e a quem suas leis protegem, devem lealdade às mesmas leis, e são membros da referida Colônia". Com o objetivo de dar maior autenticidade à representação popular nas Assembleias, os Estados passaram logo a adotar o critério de fixação do número de Cadeiras por meio da atualização do número de eleitores.

A Constituição de Nova York exigia essa medida para que "a representação permanecesse sempre proporcional e adequada" (WOOD, 2013, p. 95). É oportuno salientar que nos anos subsequentes à Declaração de Independência, a população se expandia, pela imigração, com surpreendente rapidez, situação que, aliada à enorme mobilidade social, obrigava a realização de periódicas revisões do número da representação popular em cada Casa Legislativa. Imigrantes brancos e proprietários, após cinco anos de residência no Estado adquiriam direito de voto. Cada Estado fixou a forma de eleição dos governadores e, em sua maioria, estabeleceram mandatos curtos para o cargo - um ano - com reeleições limitadas. Como o objetivo inicial dos Estados, verdadeiras Repúblicas, era concentrar o poder na representação popular, a radical Constituição da Pensilvânia eliminou o cargo de governador.

A intenção subjacente à ideia de manter as partes executiva, legislativa e judiciária do governo como entidades separadas e distintas não era proteger um poder do outro, mas salvaguardar o Judiciário e, especialmente o Legislativo da manipulação do Executivo - prática que, segundo a crença dos americanos, corrompera o Parlamento inglês. Desta forma, as novas constituições proibiram terminantemente que detentores de cargos executivos ou indivíduos que auferissem lucro a partir do governo assumissem cargos legislativos (WOOD, 2013, p.93).

Para dar maior expressão ao poder Legislativo, os Estados criaram uma Câmara Alta (Upper House), a qual, evocando a Roma Republicana, denominaram Senado, cujos membros passaram, em alguns Estados, a serem eleitos pelo povo, ao passo que, em outros, a eleição se dava pelas Assembleias Estaduais. Esta estrutura do poder legislativo estadual nos Estados Unidos ainda perdura. Hoje, em cada Estado da União, além da Assembleia Legislativa, há um Senado. Os senadores estaduais são eleitos para mandatos de quatro anos em alguns Estados, e, em outros, de dois anos. Nessa direção, na atualidade, New York conta com 62 senadores, a maior representação dos Senados Estaduais. Por sua vez, o Alasca, escassamente povoado, seu Senado comporta uma representação de 20 senadores. 
Os líderes da Revolução Americana sabiam que era preciso, além das Constituições Estaduais, criar instrumentos jurídicos que propiciassem o estabelecimento de uma união permanente dos Estados. Após quatro anos de discussão no Segundo Congresso Continental, em março de 1781, completava-se a ratificação, por todos os Estados, dos 12 Artigos de Confederação. Maryland foi o último Estado a fazê-lo. Estava criada a Confederação dos Estados Unidos da América. A Confederação, como soe acontecer nessa forma de associação de Estados, não tem um governo central. De fato, uma Confederação de Estados tem como finalidade tratar de assuntos e interesses comuns dos mesmos, como defesa, união monetária e comércio internacional, entre outros. As Confederações são instituídas por tratados. No caso dos Estados Unidos, os Artigos de Confederação, ratificados por todos os Estados, constituía o instrumento jurídico, de nítido caráter diplomático, que conformava a associação. Os assuntos da Confederação Americana eram discutidos e votados no Congresso da Confederação, ao qual os Estados enviavam, anualmente, uma delegação. Cada Estado tinha direito a um voto e seus representantes se autodenominavam embaixadores.

Assim sendo, confirmando uma das principais características das Confederações, os Estados norteamericanos conservavam a soberania, a independência, a liberdade e a jurisdição sobre todos os assuntos que não tinham sido conferidos, pelos 12 Artigos, à Confederação. Continuavam como verdadeiras Repúblicas, que mantinham uma débil aliança confederada, ou, como dispunha o artigo 30, "uma liga de Estados, unidos para a sua defesa mútua, a segurança das suas liberdades e o seu bem-estar comum”. As decisões exigiam aprovação unânime, o que logo se mostrou dificil de obter, em razão das constantes disputas econômico-financeiras entre os Estados, que travavam entre si verdadeira guerra fiscal para atrair negócios e investimentos, bem como alimentavam disputas territoriais.

O Congresso da Confederação tentava negociar acordos comerciais com outros países, porém, não encontrava receptividade, na medida em que não podia garantir o cumprimento dos mesmos pelos Estados. Não se conseguia unanimidade, por parte dos Estados, para a aprovação de direitos alfandegários destinados à composição das receitas do Tesouro da Confederação. Eram inúmeros os problemas que dependiam do Congresso. Questões como a manutenção do Exército, relações diplomáticas e celebração de tratados, cunhar moeda, estabelecer normas e procedimentos sobre assuntos dos índios, enfim, uma variedade de temas políticos, sociais e econômicos de interesse comum dos Estados, que a exigência de unanimidade para aprovação impedia sua concretização. Os Estados, no exercício de seus poderes soberanos, praticavam excessos de toda a ordem. Aprovavam leis injustas, realizavam eleições anuaís, que quase sempre eram contestadas, e ampliavam o número de membros das Assembleias por meio de expedientes em nada republicanos. Nas confederações, cujos órgãos centrais carecem de uma autoridade própria, "as pressões centrífugas, expressadas pelos interesses particulares dos Estados, tendem a prevalecer sobre as centrípetas, expressas pelos órgãos confederativos" (LEVI, 1986, p. 218). Em razão do apontado, os legisladores estaduais eram denunciados por se mostrarem exclusivamente vol.09, no. 04, Rio de Janeiro, 2016. pp. 2227-2247 2233 
interessados nos assuntos dos distritos que representavam, concediam isenções e perdões fiscais injustificados, anulavam decisões judiciais, enfim, as Assembleias Estaduais eram acusadas de "despotismo democrático" "Sob tais circunstâncias, muitas legislaturas mal conseguiam cumprir o que os revolucionários de 1776 tomaram como responsabilidade republicana: promover o bem comum" (WOOD, 2013, p. 169-170). Tal situação levou as lideranças revolucionárias, na década de 1780, a questionar as ações das Assembleias Estaduais e a forçar a revisão das Constituições Estaduais.

Esse movimento teve início no Estado de Nova York, em seguida em Massachusetts e New Hampshire e, paulatinamente, atingiu os outros Estados. Por meio de Convenções Constitucionais Estaduais, os Estados reduziram o número de representantes, os governadores passaram a ser eleitos diretamente pelo povo nos Estados que, até então, eles eram investidos pelos Legislativos estaduais em eleições indiretas. Os governadores passaram, em consequência das modificações constitucionais, a exercer todos os poderes e competências que, em geral, são atribuições do poder executivo. Os Judiciários Estaduais, independentes e livres do que Thomas Jefferson chamou de “despotismo eleito", em 1785 (WOOD, 2013, p. 173), tornaram-se guardiões das Constituições dos Estados. Os três poderes foram adequados às ideias centrais dos teóricos da matéria, Senados foram instituídos nos Estados que ainda não os havia adotado.

Voltando às dificuldades da Confederação, ao mesmo tempo em que, na citada década de 1780, as lideranças revolucionárias forçavam a revisão das Constituições Estaduais, passavam também a defender mudanças radicais nos poderes e nas ações do Congresso da Confederação. A guerra de liberação com a Inglaterra pouco avançava, o Congresso não conseguia fundos para financiar as operações militares e, principalmente, pagar os soldos e alimentar o Exército Continental. Além disso, grassava a inflação e multiplicavam-se as dificuldades para atender as despesas mais elementares da Confederação. Em 1781, com o término do mandato no Congresso da Confederação de três líderes populares radicais, Richard Lee, Arthur Lee, ambos da Virgínia, e Samuel Adams, de Massachusetts, foram substituídos por James Madison, da Virgínia, Alexander Hamilton, de Nova York e Robert Morris, da Pensilvânia, iniciou-se o movimento de reformulação do Congresso, isto é, a tentativa de fortalecer seu poder, principalmente buscar a estabilização financeira, ampliar o comércio e saldar as dívidas e o soldo do Exército Continental. Nada se conseguiu. Os Estados não aprovaram as mudanças sugeridas. A celebração da paz com a Inglaterra aumentou o desinteresse dos Estados em relação ao Congresso.

O prestígio internacional da Confederação, pelo não cumprimento de compromissos assumidos, era mínimo, situação que tornava muito difícil obter empréstimos no exterior. Motins no Exercito (a rebelião de 2.000 fazendeiros chefiados pelo capitão Daniel Shays alarmou o país), instabilidade política generalizada e a gravíssima situação econômico-financeira levaram as lideranças da Confederação a instalar, em 1786, na Filadélfia, uma Convenção Constitucional, composta por 55 delegados, sob a presidência de George Washington, para revisar os vol.09, no. 04, Rio de Janeiro, 2016. pp. 2227-2247 2234 
Artigos de Confederação. O Estado de Rhode Island, em posição de defesa radical de sua soberania, recusou-se a enviar delegados à Convenção. "Chegara a hora de pôr fim à política de liberdade e, como Hamilton o expressou, de passar ao princípio da força e da estabilidade na organização do nosso governo, e vigor em suas ações" (KRAMNICK, 1993, p. 10). A maioria dos delegados era composta por jovens intelectuais cultos, $60 \%$ tinham curso superior - 34 eram advogados -, que haviam servido, com muito valor, ao Exército Continental. Constituíam parte expressiva na elite norte-americana, "todos eram cavalheiros, 'aristocratas naturais,, ${ }^{11}$ que partiam do pressuposto de que a superioridade política era uma consequência inevitável de sua posição social" (WOOD, 2013, p. 185).

As mudanças propostas, principalmente pelo grupo federalista, acabaram propiciando, não propriamente a revisão dos Artigos de Confederação, mas a construção da Constituição, que seria aprovada em 17 de setembro de 1787. A primeira Carta Magna escrita da historia do constitucionalismo, "para promover a defesa comum e a prosperidade geral", reafirmou o conceito de nação norte-americana, apontando os Estados como apenas membros da União, portanto, dotados de autonomia e não de soberania (artigo 1º, seção 10), alicerçou-se na divisão de poderes e instituiu um presidencialismo forte, com o presidente eleito indiretamente por um colégio eleitoral. Dessa forma, " a Constituição dos Estados Unidos foi concebida com uma ampla gama de controles entre os poderes, pelos quais diferentes partes do governo podem impedir outras partes de exercer um controle tirânico" (FUKUYAMA, 2013, p. 21 e 2012, p.7).

\section{A CONSTITUIÇÃO E O SISTEMA ELEITORAL NORTE-AMERICANO}

Na construção institucional o grande e notável feito dos Fundadores dos Estados Unidos da América está expresso na Constituição Federal, documento pioneiro que, desde sua entrada em vigor, em 1789, é, seguramente, o principal fator de estabilidade política e jurídica em sua condição de fonte e pilar da identidade americana. Ao lado da Bandeira, a Constituição, que não se alterou substancialmente ao longo de mais de dois séculos, mantém-se firme como símbolo de unidade nacional. A Bandeira dos Estados Unidos sofreu modificações, em razão da criação da incorporação de novos Estados. (KRAMNICK, 1993, p. 2).

$\mathrm{Na}$ medida em que o presente texto discute a natureza constitucional do sistema eleitoral dos Estados Unidos, é conveniente salientar que a Constituição Federal do país, inicialmente apresentando apenas sete artigos, recebeu, até hoje, somente 27 emendas, das quais 11 tratam do sistema eleitoral.

\footnotetext{
${ }^{11}$ A igualdade republicana, conforme asseverava Thomas Jefferson, não eliminava todas as diferenças sociais. Contrariamente à aristocracia hereditária, artificial, as Repúblicas, na opinião de Jefferson, continuariam a ter uma aristocracia, composta por homens de qualquer origem social, porém cultos, e que, em tudo, deviam ser como os heróis da Antiguidade, que se caracterizavam pelo vol.09, nº. 04, Rio de Janeiro, 2016.pp. 2227-2247 2235
} 
É importante destacar o fato de que, no correr do Congresso Constituinte, dois grupos, federalistas e antifederalistas, se digladiavam em torno dos fundamentos ideológicos que deveriam estruturar a Constituição. A questão fulcral desse debate situava-se na defesa, por parte dos federalistas, da construção constitucional de um governo central forte e único, com verdadeira abrangência nacional, e a limitação das soberanias dos Estados, consubstanciando uma República, cuja poder soberano estava no povo.

Para construir a riqueza da Nação, os federalistas indicavam a necessidade de desenvolver a indústria, seguir o exemplo da Inglaterra, que, naquela altura, começava a colher os frutos da Revolução Industrial. Os antifederalistas queriam um país agrícola e, na questão do poder, temiam o executivo forte, pelo exemplo do que as Colônias viveram sob o jugo tirânico das autoridades que as governavam em nome da Coroa. Para eles o poder devia ficar concentrado nas Assembleias Legislativas estaduais e a soberania, em toda a sua extensão, nos Estados e nas autoridades que o representavam:

A única maneira de explicar a emergente ideia do federalismo, esta incomum divisão de responsabilidades legislativas entre o governo federal e os governos estaduais, na qual nenhum deles teria a autoridade final, era fazer do próprio povo, e não de seus representantes nas assembleias legislativas estaduais ou no Congresso, a autoridade suprema. E essa ideia se tornou modelo para divisões semelhantes do Poder Legislativo e todo o mundo. Ao declarar que toda a soberania estava no povo, os federalistas não afirmavam, como asseguraram alguns teóricos durante muito tempo, que todo o poder derivava do povo. Ao contrário, afirmavam que a soberania sempre esteve no povo, e que o governo era apenas uma concessão popular limitada e temporária - outorgada a vários representantes governamentais durante um curto período e, por assim dizer, sujeita a devolução a qualquer tempo (WOOD, 2013, p.195-196).

O sistema eleitoral que se construiu na Constituição foi profundamente influenciado por esse debate, que se deu de forma ardorosa entre os delegados à Convenção Constitucional, ou, como admitiu Alexander Hamilton, se manifestou como "uma torrente de paixões virulentas" (KRAMNICK, 1993, p. 3). O artigo 70 dispôs que a ratificação da Constituição se efetuaria após a aprovação do texto pelas Convenções Constitucionais de nove Estados e não pelas Assembleias Legislativas. Com o objetivo de persuadir os delegados à Convenção convocada pelo Estado de Nova York para ratificar a Constituição, Alexander Hamilton convidou seus confrades federalistas, James Madison e John Jay, para juntos escreverem artigos esclarecendo a importância para o país do texto aprovado na Filadélfia. Os artigos começaram a ser publicados no dia 27 de outubro de 1797, no Jornal Independent Journal, de Nova York, sob o pseudônimo único de Publius, ${ }^{12}$ e, posteriormente, em outros jornais dos Estados Unidos.

estoicismo e pelo amor à liberdade. Na visão dos americanos, George Washington era modelo de aristocrata natural, que encarnava perfeitamente o ideal clássico de líder republicano WOOD, 2013, p. 130).

${ }^{12}$ Como os três autores sofriam influência do republicanismo romano, adotaram o pseudônimo de Publius em homenagem a Valerius Publicola, aristocrata, cônsul em 503 a. C., fundador da República Roma, e um dos responsáveis pela destituição d o 7 o e último rei de Roma. 
A maioria dos 85 artigos é de autoria de Alexander Hamilton (60); Madison é autor de 20 e Jay de apenas 5. A contribuição de Madison foi importantíssima na elaboração do texto da Constituição. Assim como Thomas Jefferson foi determinante na redação do texto da Declaração de Independência, Madison foi o grande nome da Convenção que concebeu a Constituição. No Federalista $10^{13}$, apontado como o mais importante dos textos, ele trata da questão relativa à necessidade de um executivo forte e, no $51,{ }^{14}$ disserta sobre a separação dos poderes, acentuando o tema dos freios e contrapesos fundamentais para o equilíbrio dos poderes do Estado. Os Artigos Federalistas estão hoje incluídos entre os grandes clássicos da teoria política de todos os tempos.

Os antifederalistas, que, ao cabo, foram suplantados pelos federalistas, apontavam a natureza elitista, antidemocrática, conservadora e contrária aos objetivos da Revolução do texto aprovado, uma vez que os federalistas, preocupados em manter a estrutura de classe então existente e, ao mesmo tempo, em obter a aprovação popular da Constituição, como se pode observar no citado Artigo Federalista no 10, conseguiram impor suas visões de mundo, criando um sistema de representação popular, no Colégio Eleitoral encarregado de eleger o presidente, composto por um selecionado conjunto de cidadãos, "cujas ideias esclarecidas e sentimentos virtuosos, os tornam superiores a preconceitos locais" (MADISON, 1993, p. 139) e, assim, com esta condições agiriam em defesa dos verdadeiros interesses da República.

Madison criou uma metáfora, "o efeito de filtragem" para defender o que ele chamava de "governo republicando em um grande país" e para explicar a natureza elitista da Constituição. Ainda no Federalista no 10 , Madison esclarece o conceito de governo republicano, em contraposição ao governo democrático, explicando que o governo republicano tem como objetivo (1993 p. 137):

depurar e ampliar as opiniões do povo, que são filtradas por uma assembleia escolhida de cidadãos, cuja sabedoria pode melhor discernir o verdadeiro interesse de seu país e cujo patriotismo e amor à justiça serão menos propensos a sacrificá-lo a considerações temporárias ou parciais. Sob tal regulação, é bem provável que a voz pública, manifestada pelos representantes do povo, seja mais consoante com o bem público que se manifesta pelo próprio povo, convocado para esse fim.

No Federalista no 9, verifica-se o pavor dos fundadores dos Estados Unidos em relação à natureza instável e anárquica das facções políticas e pelas insurreições domésticas por elas provocadas em razão de interesses próprios:

É impossível ler a história das pequenas repúblicas da Grécia e da Itália sem experimentar horror e repugnância diante dos distúrbios que continuamente as agitavam e da rápida sucessão de revoluções que as mantinham em perpétua oscilação entre os extremos da tirania e da anarquia (HAMILTON, 1993, p. 128).

A Constituição confere ao presidente dos Estados Unidos amplos poderes. Os constituintes criaram um presidencialismo forte, fato que gerou, como acima mencionado, acirradas polêmicas entre federalistas e antifederalistas, estes partidários da descentralização do poder, da manutenção da soberania dos Estados e do governo exercido pelas Assembleias eleitas por voto popular direto. "Há poucos símbolos mais importantes da Revolução de 1787 que o espantoso poder que a Constituição deu ao novo primeiro-magistrado, encarnação ideal de autoridade, governo e poder" (KRAMNICK, 1993, p.27). Para Edmund Randolph, que foi o $2^{\circ}$ secretario

\footnotetext{
${ }^{13}$ Consultar o texto completo, em inglês, do Artigo Federalista $n^{a}$ 10, em MADISON, 1999, p. 160/167. O texto em português pode ser lido em MADISON, James; HAMILTON, Alexander; e JAY, John, 1993, p. 133/139.
} 
de Estado dos Estados Unidos e o primeiro procurador-geral do país, o poder conferido pela Constituição ao presidente era o "feto da monarquia. Para os antifederalistas, ele seria "nosso novo rei" (KRAMNICK, 1993, p.26).

A Constituição, inicialmente, estabeleceu que o presidente e o vice-presidente poderiam ser reeleitos indefinidamente. George Washington, primeiro presidente, foi reeleito para um segundo mandato, porem, recusou a terceira reeleição. Até 1912, nenhum presidente tentou um terceiro mandato. Nessa época, abrindo uma cisão no Partido Republicano, Theodore Roosevelt, presidente entre os anos 1901/1909, lançou-se candidato a um terceiro mandato, pelo Partido Progressista. Foi derrotado por Woodrow Wilson. Em 1940, Franklin Roosevelt, em plena guerra, e talvez por isso, foi reeleito para um terceiro mandado. Em 1945, reelegeu-se para um quarto período presidencial, porém, faleceu logo após a posse, em 12 de abri de 1945.

Em 27 de fevereiro de 1951 entrou em vigor a 22a emenda à Constituição Federal, determinando que "ninguém poderá ser eleito mais de duas vezes presidente dos Estados Unidos". Sobre a vice-presidência, de acordo do com a 25a Emenda, ratificada em 1967, havendo vacância do cargo, o presidente, de acordo com a Constituição, nomeará um novo vice, que se empossará, uma vez confirmado pelas duas Casas do Congresso. Dois vice-presidentes foram nomeados dessa forma. Gerald Ford, em 1973, em decorrência da renúncia do vicepresidente Spiro Agnew e Nelson Rockefeller, em 1974, quando Ford assumiu a presidência, em razão da renúncia de Richard Nixon.

Foram as questões teóricas anteriormente mencionadas, e a dúvida sobre a conscientização do povo, que levaram os constituintes de 1787 a tirar do povo a possibilidade de escolher diretamente o presidente e os senadores, e a criar o Colégio Eleitoral para eleger o presidente e o seu vice-presidente (art. II da Constituição, emendado em 1804, 1951 e 1961) e determinar que os senadores - dois por cada Estado, para um mandato de seis anos - fossem eleitos pelas respectivas assembleias estaduais A escolha indireta dos senadores da República vigorou até a ratificação, em 8 de abril de 1913, da 17a Emenda à Constituição Federal, a partir da qual os senadores passaram a ser eleitos por voto direto. Ainda sob o aspecto elitista, os constituintes aprovaram que o direito de voto era privilégio do cidadão proprietário, cuja regulamentação ficou a cargo de cada Estado.

Esta restrição ao voto popular já não mais vigora, conforme a 24a Emenda, de 1969. Na visão dos "Pais Fundadores" federalistas a participação direta do povo seria na eleição à Câmara dos Representantes, cujas decisões estariam, por sua vez, sujeitas à revisão do Senado. Para candidatar-se ao Senado Federal estabeleceu-se que o cidadão deveria ter, no mínimo, 30 anos. Cada Estado tem direito a dois senadores, sendo que um terço dos assentos é submetido a eleições de dois em dois anos. Republicanos e Democratas, alternadamente, controlam o Senado desde 1860. A 27ª Emenda, ratificada em 8 de abril de 1913, dispõe:

\footnotetext{
${ }^{14}$ Ibidem, p. $294-299$ e p. 349-352
} 
Quando no Senado ocorrem vagas na representação de qualquer Estado, o Poder Executivo desse Estado expedirá editais de eleição para o preenchimento das vagas, podendo, porém, a Legislatura de qualquer Estado autorizar o Poder Executivo a fazer nomeações provisórias até que o povo preencha as vagas por eleição conforme prescrever a Legislatura.

A Câmara dos Representantes, de acordo com a da Constituição, é composta por membros eleitos para um mandato de dois anos pelos eleitores dos seus estados. A idade mínima para se candidatar à Câmara é de 25 anos. O número de representantes por Estado é fixado de acordo com a população do mesmo Estado. Cada assento na Câmara dos Deputados representa um distrito único, e cada membro é eleito a partir de um distrito único segundo a regra da pluralidade, isto é, o candidato mais votado ganha a Cadeira. Cada um dos 50 Estados tem assegurado pelo menos uma vaga na Câmara dos Representantes. O Alasca, com população escassa, tem somente um. A Constituição, ao instituir o Poder Legislativo bicameral, buscou impedir que ele se tornasse um poder por demais forte, o que afetaria a divisão de poderes. ${ }^{15}$. estrutura fundamental do sistema eleitoral dos Estados Unidos foi estabelecida, portanto, em 1787, pela Constituição, que não determinou a obrigatoriedade do voto. Por outro lado, conferiu aos Estados plena autonomia para legislar sobre os processos acerca da realização de eleições em seus territórios. A forma de escolha dos candidatos aos diversos cargos da República, também ficou sob a autonomia dos Estados que, em conjunto com os Partidos, estabelecem as normas para a realização dos caucases, eleições primárias e convenções para a nomeação dos candidatos. Disso resultou o fato de que a eleição presidencial não se realiza de acordo com normas nacionais uniformes, a não ser nas situações previstas na Constituição, gerando 50 eleições diferentes. Não há contagem nacional dos votos. Cada Estado realiza, de acordo com suas normas internas, a eleição e a apuração dos votos.

Retornando aos aspectos históricos do sistema, em razão do aumento da população nos anos iniciais do século XIX - em 1790 os Estados Unidos tinham 3,9 milhões de habitantes, números que foram elevados, em 1870, para 40 milhões - e, da mesma forma, em consequência da expansão territorial do país com a aquisição de territórios - a Luisiana à comprada à França, em 1803, a Flórida à Espanha, em 1819, o Alasca ao Império Russo, em 1867 e, especialmente, a incorporação dos territórios tomados ao México, Texas, Califórnia, Nevada, Utah, Arizona e Novo México, o sistema eleitoral, começou a ser modificado, em 1804, com a aprovação da 12a Emenda à Constituição Federal, medida que estabeleceu procedimentos mais precisos sobre a eleição presidencial.

É interessante destacar que essa primeira modificação na estrutura do sistema eleitoral criado pela Constituição deu-se em razão de acontecimentos polêmicos nas eleições presidenciais de 1796 e 1800. Em 1796, na sucessão do presidente George Washington, que recusou um terceiro mandato, como já foi dito, seu vice-

\footnotetext{
${ }^{15}$ O Censo de 2010 mudou o Colégio Eleitoral e o número de Cadeiras no Senado e na Câmara dos Representantes, em vários Estados. Destes, oito ganharam votos, devido a redistribuição de acordo com a nova realidade populacional de cada um: Arizona, Flórida, Geórgia, Nevada, Carolina do Sul, Texas, Utah e Washington. Dez Estados perderam votos: Illinois, Iowa, Louisiana, Massachusetts, Michigan, Missouri, Nova Jersey, Ohio e Pensilvânia.
} 
presidente, John Adams, pelo Partido Federalista, lançou-se candidato à presidência, apoiando o governador da Carolina do Sul, Thomas Pinkney, como candidato a vice. Antes da aprovação da 12a Emenda, os delegados ao Colégio Eleitoral votavam duas vezes para presidente. O mais votado era sagrado presidente e o imediatamente mais votado seria o vice-presidente, que concorria separadamente, pois não havia o que hoje se denomina running mate, a chapa dupla. Em 1796, doze candidatos concorreram à presidência. A disputa principal se deu entre os candidatos John Adams e Thomas Pinkney, que, aliados, enfrentaram Thomas Jefferson e Aaron Burr, apoiados pelo Partido Democrata-Republicano. John Adams foi eleito presidente e seu adversário político, Thomas Jefferson, vice-presidente. Quatro anos depois, na terceira eleição presidencial, John Adams, candidato à reeleição foi derrotado no colégio eleitoral por Thomas Jefferson e Aaron Burr, que acabaram empatados na votação.

A eleição, de acordo com o art. $2^{\circ}$, seção I, da Constituição, seria decidida, para a presidência da República, na Câmara dos Representantes e, para vice, pelo Senado. Os federalistas, tentando impedir a eleição de Thomas Jefferson, votavam em Aaron Burr. A divisão levou a eleição a um impasse e somente foi decidida, em favor de Jefferson, após 36 escrutínios. Sabe-se que Thomas Jefferson foi eleito em razão do apoio que the foi dado por Alexander Hamilton, que o detestava por diferenças ideológicas, ou seja, Jefferson queria que os Estados Unidos se transformassem em uma grande nação agrícola, com um poder central fraco, enquanto Hamilton defendia um presidencialismo forte, a industrialização e o desenvolvimento das bases do capitalismo corporativista no país. ${ }^{16}$ Contudo, como Hamilton detestava, mais ainda, a Aaron Burr, no último escrutínio apoiou Thomas Jefferson. Este fato agravou as relações entre Alexander Hamilton e Aaron Burr, que decidiram resolver suas desavenças em um duelo que resultou na morte de Alexander Hamilton, em 1804, aos 49 anos de idade.

\section{O COLÉGIO ELEITORAL}

O Colégio Eleitoral elege o presidente e o seu vice. É formado por um grupo de cidadãos escolhidos em cada Estado, de acordo com as normas estaduais pertinentes. O número de delegados por Estado é determinado pelo número de senadores - dois - somados aos representantes do Estado na Câmara Federal e é variável, conforme a população apurada nos Censos decenais. A 13a Emenda confere ao Distrito de Columbia o direito de designar delegados, em quantidade nunca inferior ao Estado menos populoso. Atualmente, o Colégio Eleitoral é composto por 538 membros, que correspondem à representação nas duas casas do Congresso: 100 Senadores + 435 Deputados 3 Delegados de Washington, D.C. Para se eleger o candidato precisará receber, no mínimo, 270 votos. No Federalista n 64, o "Pai Fundador" John Jay, justificando a natureza elitista do Colégio Eleitoral, escreve

\footnotetext{
${ }^{16}$ Hamilton fundou o Bank of New York, em 1784, instituição bancaria mais antiga dos Estados Unidos e que, após 220 anos de existência, em 2007, fundiu-se com a Mellon Financial Corporation, sob a denominação de Bank of New York Mellon.
} vol.09, nº. 04, Rio de Janeiro, 2016. pp. 2227-2247 
o seguinte:

A Convenção [...] recomendou que o presidente seja escolhido por corpos seletos de eleitores, que receberão delegação do povo para este fim específico, e confiou a designação dos senadores aos legislativos estaduais. Este procedimento tem, nesses casos, enorme vantagem sobre eleições pelo povo como coletividade, em que a ação do fervor partidário, tirando proveito da apatia, da ignorância e das esperanças e temores dos incautos e ambiciosos, consegue com frequência eleger homens pelos votos de pequena proporção dos eleitores. Dado que as assembleias seletas para a escolha do presidente [...] se comporão em geral dos mais esclarecidos cidadãos, há razões para se presumir que sua atenção e seu voto se inclinarão para os homens que mais se tiverem destacados por suas capacidades e virtude, e em quem o povo percebe justos motivos para confiar (1993, p. 411-412).

Os princípios essenciais estabelecidos pelos Fundadores dos Estados Unidos para a escolha indireta do Presidente - as bases do Colégio Eleitoral expressas, até 1804, no artigo 2º, seção 1, nº 3, da Constituição e, a partir daí, pela 12a Emenda, não foram substancialmente alterados nos últimos 200 anos. O Colégio Eleitoral é composto por pessoas que não ocupam cargos públicos nacionais. A questão da forma da eleição do Presidente figurou no rol dos problemas mais difíceis dentre os enfrentados pelos constituintes de 1787.

A polêmica se estabeleceu em torno de duas propostas: eleição popular direta, ou escolha do presidente pelo Congresso. A primeira foi considerada excessivamente democrática pela maioria dos delegados. Na Convenção Constitucional, o grupo federalista, externando seu elitismo, mostrou-se contrário à proposta, alegando que o país possuía dimensão continental, pouco povoado naquela época, e que, em razão disso, os eleitores, espalhados pelo território nacional, não conheciam os candidatos, não tinham como fazer um juízo perfeito sobre os mesmos. A escolha do presidente, na linha do que federalista John Jay afirma no texto acima citado, para James Madison, deveria ser confiada a um grupo de pessoas, cuja sabedoria poderia melhor discernir o verdadeiro interesse do seu país (1993, p. 136), e que, além disso, conhecia as qualidades dos candidatos, e, assim, teria o bom senso necessário para a escolha das melhores pessoas para os dois cargos mais importantes da Nação.

A segunda proposta, eleição indireta pela Câmara dos Representantes, foi rejeitada. Os convencionais de 1787 acabaram optando por uma solução conciliatória, formalizada no Colégio Eleitoral, mecanismo que manteria afastado o cidadão comum do processo de escolha direta do Presidente, cabendo às elites políticas de cada Estado, por meio das Assembleias Legislativas, o poder para decidir como seriam escolhidos os membros do Colégio Eleitoral, os chamados “Grandes Eleitores”, e, da mesma forma, como seriam os dispositivos de votação, os procedimentos para a apuração e as formas para a proclamação do vencedor em cada Estado. Ao longo de dois séculos, várias emendas à Constituição foram propostas, sem êxito, para modificá-lo. Como a eleição é decidida Estado por Estado, são 50 disputas presidenciais, como já foi dito, realizadas sob regras diversas. Se nenhum dos candidatos consegue os 270 votos mínimos, zera-se tudo, e a disputa vai para a Câmara dos Representantes - um voto por cada Estado, sem distinção entre grandes e pequenos. Nesse caso, o Distrito de Columbia fica fora do certame, por não possuir representação no Congresso americano. 
A escolha dos delegados ao Colégio Eleitoral se dá no dia da eleição presidencial. Realizada a votação para presidente em cada Estado, o partido que obtiver a maioria dos votos populares indica todos os delegados daquele Estado (sistema winner takes-all). Apenas dois Estados não o adotam - Maine e Nebraska. Nestes Estados, os delegados são escolhidos proporcionalmente aos votos populares conferidos a cada candidato. $\mathrm{O}$ sistema winner takes-all pode levar a uma situação um tanto anacrônica, ou seja, um candidato, no cômputo geral, ganha a eleição por maioria de votos populares e não leva a presidência. Basta que ele perca, por diferença mínima, nos Estados mais populosos, nos maiores colégios eleitorais. De acordo com a $12^{\mathrm{a}}$ Emenda o processo de eleição do presidente e de seu vice se dará da seguinte forma:

Os eleitores se reunirão em seus respectivos Estados e votarão por escrutínio para Presidente e Vice-Presidente; usarão cédulas separadas, numa das quais indicarão o nome em que votaram para Presidente, consignando na outra cédula o nome do Vice-Presidente; enumerarão em listas distintas os nomes de todas as pessoas sufragadas para Presidente e para Vice-Presidente, assim como o número de votos obtidos por cada uma delas; assinarão e autenticarão estas listas e as enviarão seladas à sede do Governo dos Estados Unidos, dirigindo-se ao Presidente do Senado.Todas as cédulas serão por este abertas perante ambas as câmaras, contando-se os votos. Será eleito Presidente o candidato que reunir maior número de votos para esse posto, se esse número representar a maioria dos eleitores designados. Se ninguém obtiver essa maioria, a Câmara dos Representantes escolherá imediatamente por escrutínio o Presidente, dentre os três candidatos mais votados para a Presidência. Mas na escolha do Presidente se tomarão os votos por Estados, tendo direito a um voto a representação de cada um dos Estados. Para esse propósito, o quórum consistirá de um membro ou membros de dois terços dos Estados, sendo necessária para a eleição a maioria de todos os Estados.

O presidente e o vice-presidente prestam juramento e são empossados no dia 20 de janeiro seguinte à eleição. Este sistema só funciona bem quando o eleito recebe expressiva votação, tanto no voto popular quanto no Colégio Eleitoral. Todas as vezes que assim não foi, o seu anacronismo veio à tona, abrindo crises políticas e levando às situações nada democráticas, como a possibilidade de um candidato ganhar na soma geral dos votos populares e perder a eleição.

Em 1824, Andrew Jackson ganhou no voto popular, mas foi John Quincy Adams, seu adversário, que foi morar na Casa Branca. Em 1876, Samuel Tilden foi o preferido na contagem geral, mas Rutherfor B. Hayes levou a melhor no Colégio Eleitoral. Da mesma forma, em 1888, Grover Cleveland, disputando o segundo mandato, perdeu a presidência para Benjamim Harrison no Colégio Eleitoral, embora vitorioso na votação popular. Em 2001, Al Gore passou pela mesma experiência amarga. Este sistema é, de fato, bastante complexo. Em 1948, Harry Truman derrotou Thomas Dewey por mais de 2 milhões de votos populares de diferença, mas, se apenas 12 mil eleitores da Califórnia e de Ohio tivessem votado em Thomas Dewey nestes Estados, a eleição teria sido levada à Câmara de Representantes, para a escolha do Presidente entre os 3 candidatos mais votados. Portanto, em nenhuma das alternativas, a eleição pelo Colégio Eleitoral ou escolha pela Câmara dos Representantes, votando por Estados, o princípio democrático básico "um homem, um voto" é respeitado na eleição presidencial norteamericana. 
Vale também registrar que, em 1912, o democrata Woodrow Wilson foi eleito sem obter maioria no voto popular. Neste século, a questão da reforma do sistema de escolha do Presidente veio á baila nas polêmicas eleições de 1948, 1960, 1968, 1976 e em 2000. A eleição presidencial de 1960 foi uma das mais disputadas na história americana. Talvez a mais disputada. John Kennedy obteve 303 votos no Colégio Eleitoral, com 49,7\% no voto popular. Richard Nixon obteve 219 votos no Colégio Eleitoral e 49,5\% no voto popular. Nas últimas décadas do século passado, várias propostas para modificação do Colégio Eleitoral chegaram a ser discutidas no Congresso, sem êxito.

\section{O SISTEMA PARTIDÁRIO DOS ESTADOS UNIDOS}

Os constituintes de 1787 não se preocuparam, melhor dizendo, não previram a criação de um sistema partidário para o país. Daí a liberdade para qualquer cidadão se apresentar ao eleitorado de forma independente. Como já foi anteriormente mencionado, os fundadores dos Estados Unidos, por temer a força desestabilizadora das facções políticas, de início, pretendiam preservar a jovem república dos partidos políticos. George Washington foi eleito pelo Colégio Eleitoral sem qualquer ligação partidária. Apesar disso, já em 1800, os EUA apareciam como o primeiro país do mundo a organizar partidos nacionais. É interessante salientar que os partidos se formaram a partir da aglutinação de políticos em torno de grandes líderes. Em 1790, os federalistas seguidores de Alexander Hamilton tornaram-se uma poderosa facção que se organizou para disputar cadeiras no Congresso e para votar os programas propostos pelo líder. O Partido Federalista foi o primeiro partido político dos EUA, fundado, em 1794, e dissolvido em 1823.

Alexander Hamilton foi o criador da legenda, que tinha como princípios o federalismo, o nacionalismo e a industrialização. Na eleição presidencial de 1796 dois partidos estavam no centro da disputa: o Partido Federalista, de Hamilton, e o Democrata-Republicano de Thomas Jefferson, fundado em 1791. Dissolvido em 1825, esse partido tinha como fundamento programático, a democracia, a defesa da pequena propriedade agrícola e a autonomia dos Estados. Elegeu quatro presidentes até sua dissolução. A oposição de Madison aos programas de Hamilton no Congresso abriu caminho para a formação de um partido rival, o grupo dos republicanos.

Dois partidos, daí em diante, passavam a disputar a eleições: os republicanos e os federalistas. Em 1820, o grupo republicano criou o Partido Democrático Republicano. Em 1830 os dois partidos estavam organizados para enfrentar o desafio de arregimentar os eleitores, uma vez que, àquela altura, com a aprovação no Congresso da retirada da exigência de que o eleitor fosse proprietário de terras, ampliava-se consideravelmente o número de novos votantes. Em 1833, advogado e político Henry Clay, inspirado nos Whigs ingleses, e com um programa voltado à defesa do protecionismo e da modernização dos Estados Unidos, fundou o Partido Whig. Seu objetivo imediato era fazer oposição ao presidente Andrew Jackson e ao Partido Democrata, fundado por ele em 1836. 
Entre 1841 e 1853 o Whig Party elegeu quatro presidentes. Dissolveu-se definitivamente em 1860.

Em 1856 as facções e grupos políticos estavam aglutinados em torno dos dois partidos, que até hoje dominam a cena política americana: Republicanos e Democratas. O Partido Republicano, o Grand Old Party, tal como se apresenta hoje, é de 1854. Foi fundado no Estado de Wisconsin por abolicionistas que se opunham à expansão da escravatura para os territórios do Oeste, e por facções do Partido Whig. Sua primeira convenção se realizou em 6 de julho de 1854, na cidade de Jackson, Michigan. Em 1856 lançou seu primeiro candidato à presidência dos Estados Unidos, o engenheiro John Charles Fremont, que foi derrotado pelo democrata James Buchanan, político que é considerado o pior presidente da história dos Estados Unidos. O Partido Republicano se fortaleceu durante e após a Guerra Civil, em razão do incontestável apoio que prestou à causa da abolição. O Exército Nortista era composto, em grande parte, por soldados e oficiais republicanos.

O Partido desempenhou importante papel na aprovação da 13a Emenda à Constituição dos Estados

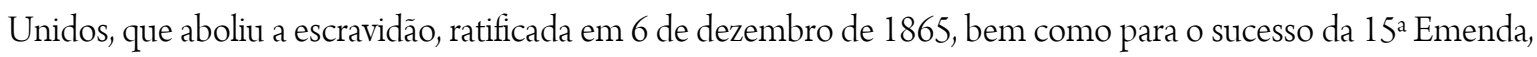
ratificada em 3 de fevereiro de 1870 e que dispôs o seguinte: "O direito de voto dos cidadãos dos Estados Unidos não poderá ser negado ou cerceado pelos Estados Unidos, nem por qualquer Estado, por motivo de raça, cor ou de prévio estado de servidão". O Partido Republicano elegeu, até hoje, 18 presidentes; o primeiro foi Abraham Lincoln, em 1861, e o último George W. Bush, em 2001.

O Partido Republicano, em síntese, conforma hoje em sua composição várias correntes de viés conservador, contrárias a união homoafetiva, às pesquisas em células-tronco e à eutanásia. Seus adeptos se distribuem entre uma direita cristã, que reúne protestantes brancos e católicos conservadores, além de mórmons e judeus ortodoxos; os chamados conservadores sociais são defensores da família tradicional e contrários à legalização das drogas; por seu turno, os conservadores fiscais se batem pela redução de impostos, pelo estadomínimo, defendem as privatizações, o fim dos programas sociais e são contrários à abolição da pena de morte. Ao lado desses grupos, republicanos neoconservadores defendem as intervenções militares no exterior, e todos são favoráveis ao porte de armas. O Tea Party é, no âmbito do Partido Republicano, um movimento e não propriamente uma facção. Seus membros agregam e defendem algumas das teses adotadas pelas várias facções do Partido, como questões fiscais, especialmente redução de impostos, o estado mínimo, a recusa de qualquer iniciativa liberal em relação à imigração, entre outras medidas.

O Partido Democrata foi fundado em 1828 por facções que saíram do extinto Partido DemocráticoRepublicanos, criado por Thomas Jefferson. Em 1829 elegeu seu primeiro presidente dos Estados Unidos, Andrew Jackson. No século XIX os democratas estavam fortemente ligados aos interesses do sul escravocrata. Durante a guerra civil ofereceram resistência ao aumento de impostos para financiar o conflito e boa parte da bancada se opôs à 13a Emenda à Constituição Federal, que, ratificada em 6 de dezembro de 1865, emancipou os escravos nos Estados Unidos. Esta posição prejudicou bastante a evolução do Partido Democrata até, vol.09, no. 04, Rio de Janeiro, 2016. pp. 2227-2247 2244 
praticamente, as primeiras décadas do século XX. Nos anos 30 do século passado, os bem sucedidos esforços do presidente Franklin Roosevelt para livrar o país das consequências desastrosas da Grande Depressão, ou seja, os projetos sociais e os programas para criar empregos na cidade e no campo, reduziram a desigualdade social, a economia voltou a crescer, puxada pela indústria e pelo desenvolvimento tecnológico.

Desde então, o Partido Democrata passou a adotar uma linha política de centro e de economia mista, aprofundou as políticas voltadas à justiça social, à defesa do consumidor e do sistema universal de saúde, enfim uma postura política que trouxe para as suas fileiras os sindicatos, a maioria dos intelectuais e artistas, os grupos minoritários, como $80 \%$ dos negros, mais de $50 \%$ dos latinos e de $60 \%$ dos judeus. Sob o prisma religioso, católicos, muçulmanos e protestantes negros votam no Parido Democrata, enquanto 64\% dos ateus e agnósticos norte-americanos são também eleitores do Partido. A aprovação da lei dos direitos civis no governo Lyndon Johnson no contexto do seu projeto da Grande Sociedade, as iniciativas de combate a pobreza, de proteção ambiental e de auxílio à educação, ampliaram o apoio dos chamados grupos progressistas ao Partido Democrata. Esses dois partidos norte-americanos, que monopolizam a vida política do país, não nasceram de movimentos sociais e ideológicos, como a grande maioria dos partidos europeus criados a partir da segunda metade do século dezenove. Democrata e Republicano são partidos de estrutura descentralizada e flexível, caracterizados pela inexistência em seus âmbitos de disciplina e de rigidez hierárquica. São, de fato, partidos liberais, com facções e grupos internos mais à esquerda ou mais a direita.

É um falso bipartidarismo, se o confrontamos com sistema inglês que é marcado por rígida disciplina partidária. Como republicanos e democratas dominam a cena política, têm-se a impressão de que existem somente dois partidos no país. De fato, existem algumas dezenas de outras agremiações políticas, de conteúdo ideológico/programático variado, mas, em sua grande maioria, de total insignificância eleitoral.

\section{CONSIDERAÇÕES FINAIS}

O Sistema Eleitoral dos Estados Unidos, criado pela Constituição de 1787, em decorrência de acontecimentos polêmicos nas eleições presidenciais de 1796 e 1800, começou a ser modificado, em 1804, a partir da aprovação da 12a Emenda à Constituição Federal. Desde então, onze novas Emendas foram adicionadas ao texto constitucional regulando o processo de escolha dos governantes do país. Assim, para adaptar a estrutura constitucional eleitoral às mudanças sociais e políticas, a partir da citada $12^{a}$ Emenda, outras importantes alterações constitucionais foram aprovadas: a 14a , de 1868, que estabelece proteções e privilégios eleitorais aos cidadãos do EUA; a que instituiu o direito de voto para todas as raças (15ª Emenda, 1870); a eleição direta dos senadores (17a Emenda, 1913); o direito de voto às mulheres (19a Emenda, 1920); a que estabelece datas para o término dos mandatos dos Senadores e da Câmara dos Representantes (20a Emenda, 1933); a que trata dos 
limites do mandato presidencial (22a, 1951); a que confere ao Distrito de Columbia o direito de participar do Colégio Eleitoral (23a , de 1961); a que proibiu o cerceamento do direito de voto de qualquer cidadão em razão de não haver pago qualquer imposto eleitoral, ou algum outro imposto (24a Emenda, 1964); a que regula o processo de destituição do Presidente (25a , de 1967); e a que ordena que não será negado ou cerceado pelos Estados Unidos ou por qualquer dos Estados, o direito de voto ao cidadão de dezoito anos de idade, ou mais (26a de 1971).

A Federação norte-americano confere aos Estados ampla liberdade para legislar sobre o processo eleitoral em seus territórios. Como não há uma Justiça Eleitoral, a exemplo do que acontece no Brasil e em outros países, a existência de normas eleitorais distintas em cada Estado, para a escolha dos chamados "Grandes Eleitores”, ou seja, os cidadãos que deverão compor o Colégio Eleitoral que elege o presidente e o vice-presidente, resulta disso cinquenta eleições presidenciais de certa forma diferenciadas, fato que expõe a complexidade do Sistema. Sob o prisma democrático, as criticas ao modelo eleitoral norte-americano concentram-se na natureza indireta da eleição presidencial que, em seus fundamentos ideológicos, sob alegação exposta nos Artigos Federalistas de que a voz pública manifestada pelos chamados "Grandes Eleitores", apresenta-se mais adequada à defesa do bem comum do que a expressa pelo próprio povo, não se modificou em relação ao padrão idealizado pelos “Pais Fundadores" dos Estados Unidos da América.

\section{HISTORICAL AND CONSTITUTIONAL BASIS OF THE ELECTORAL SYSTEM OF UNITED STATES OF AMERICA}

\section{Abstract}

The main objective of this article is to discuss the creation process by the "Founding Fathers" of the United States of America, of the electoral system of the country and its historical and constitutional evolution, from the XII Amendment (1804) to the Constitution of 1787. It also seeks to analyze the role of the Union States in building this system, the development of the party structure and the ideological basis of the Electoral College, which chooses the president and vice president of the United States, and are expressed in the Federalist Papers.

Keywords: United States electoral system. American Constitution. Federalist Papers. Electoral College.

\section{REFERENCIAS}

ARENDT, Hannah. Sobre a Revolução. Tradução de Denise Bottmann. São Paulo: Companhia das Letras, 2011.

FUKUYAMA, Francis. As Origens da Ordem Política. Tradução de Nivaldo Montingelli Jr. Rio de Janeiro: Rocco, 2013. 
The Origins of Political Order. New York: Farrar, Straus and Giroux, 2012.

JOHNSON, Paul. Estados Unidos - La Historia. Traducción Fernando Mateo y Eduardo Hojman. Barcelona: Javier Vergara Editor, 2001.

KIERNAN, V. G. Estados Unidos - O Novo Imperialismo - Da Colonização Branca à Hegemonia Mundial. Tradução de Ricardo Doninelli Mendes. Rio de Janeiro: Record, 2009.

KISSINGER, Henry. Diplomacia das Grandes Potências. Tradução de Saul S. Geffer e Ann Mary Fighiera Perpétuo, revista por Heitor de Aquino Ferreira. Rio de Janeiro: Francisco Alves, 2001.

KRAMNICK, Isaac. Apresentação dos Artigos Federalistas. In: MADISON, James, HAMILTON Alexander e JAY, JOHN. Os Artigos Federalistas 1787-1788. Tradução de Maria Luiza X. de A. Borges. Rio de Janeiro: Nova Fronteira, 1993, p. 1-86.

LEVI, Lucio. Confederação. In: BOBBIO, Norberto et alii. Dicionário de Política. Tradução de Carmen C. Varrialle et alii. Brasília: Editora UnB, 1996, p. 218-220.

MADISON, James; HAMILTON, Alexander; JAY, John. Os Artigos Federalistas - 1787 -1788. (Edição integral) Apresentação por Isaac Kramnick. Tradução de Maria Luíza X. de A. Borges. Rio de Janeiro: Nova Fronteira, 1993.

Writings. New York: Literay Classics of United States, Inc. 1999.

NYE JR, Joseph. O Paradoxo do Poder Americano. Tradução de Luiz Antônio Oliveira de Araújo. São Paulo: UNESP, 2002.

PARENTI, Michel. A Cruzada Anticomunista. Tradução de Marcelo Guimarães. Rio de Janeiro: Civilização Brasileira, 1970.

PEREIRA, Antônio Celso Alves. Os Impérios Nucleares e seus Reféns - Relações Internacionais Contemporâneas. Rio de Janeiro: Graal, 1984.

RAPHAEL, Ray. Mitos sobre a Fundação dos Estados Unidos - A verdadeira história da Independência norteamericana. Tradução de Maria Beatriz de Medina. Rio de Janeiro: Civilização Brasileira, 2006.

TOCQUEVILLE, Alexis. A Democracia na América. Tradução de Neil Ribeiro da Silva. Belo Horizonte: Itatiaia, 1987.

WOOD, Gordon S. A Revolução Americana. Tradução de Michel Teixeira. Rio de Janeiro: Objetiva, 2013.

Trabalho enviado em 29 de setembro de 2016.

Aceito em 01 de novembro de 2016. 